\title{
US Congress urged to back further Agent Orange studies
}

Washington. A report prepared for the US Congress by the Institute of Medicine (IoM) this week called for yet further investigation of the effects of the defoliant Agent Orange on the health of Vietnam veterans.

Congress commissioned the 500page report in a bid to clear up the longrunning controversy over Agent Orange, a herbicide the Americans sprayed extensively during the Vietnam war. The report overturns previous recommendations by several official agencies that further investigation would be futile because it was difficult to gather reliable data on exposure of veterans.

The US Department of Veterans Affairs already compensates exposed veterans who have developed non-Hodgkin's lymphoma, soft tissue sarcoma, and chloracne. But the report says there is now sufficient evidence to link exposure with Hodgkin's disease and the liver disorder porphyria cutanea tarda (PCT) as well.

But for a far longer list of alleged health problems - including various cancers, infertility and birth defects - it says there is insufficient evidence to establish such a link.

House and Senate veterans affairs committees will this week start hearings to consider the report. The Department of Veterans Affairs is expected to respond within 90 days, possibly by widening its compensation rules.

An IoM panel prepared the report for the National Academy of Sciences. The inquiry was intended to inject some balance into what historically has been a highly polarized debate between angry veterans and sceptical government agencies. Veterans' organizations were furious, for example, when the Centers for Disease Control concluded in 1989 that it was impossible to untangle the Agent Orange episode (see Nature 340, 179; 1989).

The panel, chaired by Dr Harold Fallon of the University of Alabama, recommends that a nongovernmental body should look for new ways to estimate exposure of veterans, particularly those not involved in spraying. An independent panel should then evaluate these techniques, it says; if they found them adequate, the government should then start an extensive epidemiological study to assess possible links between Agent Orange and cancer and other diseases.

Dr David Tollerud of the University of Pittsburgh, vice-chairman of the panel, says that such an investigation, deemed impractical a few years ago, is now worthwhile: "Several things have changed. First, we got information that substantial amounts of herbicide were used around US bases and on waterways, but not recorded. Second, newer approaches in epidemiology allow us to combine informal as well as formal data in models. Finally, we have better computer hardware and software. So it may be possible to develop a useful model."

"We are not saying that a big epidemiological study should be done," says Tollerud. "We just outline various steps that should be taken in preparation for one." The IoM panel did not cost the preparatory work or the study, or suggest their priority compared

with other health research.

Congress asked the National Academy of Sciences only to review and evaluate existing scientific and medical information on Agent Orange. But the panel made research recommendations because, Tollerud says, "we felt an ethical obligation to go beyond just stating the scientific facts".

The report touches briefly on prospects for research on the effects of Agent Orange on the health of Vietnamese civilians: the United States sprayed 11.2 million gallons on their homes and crops between 1962 and 1970. But Tollerud says the report did not recommend a Vietnamese study because an investigation of US war veterans "is more tractable and more relevant to what we were asked for".

Colin Macilwain

\section{Russian science nearing collapse}

Moscow. Russian science may now be on the brink of collapse, following the suspension of payments by the Russian Academy of Sciences (RAS) to its dependent institutes.

In many institutes, salaries are not now being paid. At the Institute for Molecular Genetics in Moscow, for example, employees have been given extended leave without pay over the summer months. At the Institute of Applied Mathematics, the administration is paying only 40 per cent of agreed salaries. Elsewhere, funds intended for equipment and supplies are being spent on salaries instead.

Both the Minister for Science, Boris Saltykov, and the president of the RAS, Yurii Ossipov, have used the phrase "brink of collapse" in their comments on this situation, which has arisen unexpectedly, and after a short spell when Russian scientists sensed some improvement of their financial condition for the first time since the reforms began.

What has gone wrong? At the beginning of the year, the budget of the RAS was increased nearly threefold, from 250 billion rubles to 680 billion rubles. Although this was not agreed by the Supreme Soviet, payments by the academy in the first half of the year were based on the increased budget. Moreover, by a decree of President Boris Yeltsin, the salaries of all RAS employees were increased by a factor of 1.9 .

Now, it seems, these promises will not be kept. At the end of June, the finance ministry told Saltykov's office that the index factor would be 1.47 , not 1.9. In the meantime, the RAS ran out of funds. Institute salaries for May were not paid. Only early in July was there a payment to cover salaries for May and part of June.

The effects of the payments freeze vary from one institute to another. Those earning a large proportion of their income from sources other than the RAS may be able to weather the crisis without serious disruption. But reports from other institutes describe hardship and even hunger among researchers.

Ossipov has told the newspaper Izvestyia that, in this precarious situation, the Russian academy is "balanced on the brink of unstable equilibrium, where a slight push will cause everything to collapse". Institute researchers feel badly let down by the government. The research community gave Yeltsin its support in the hard times before the referendum in April, and had believed that better treatment for the research community would be their reward.

Now the mood among researchers has shifted. At an extraordinary conference on 30 June, the RAS trade union called on its members to be ready to strike, and demanded of the government and of Yeltsin that an effort should be made to settle financial relations between the state and science. An unprecedented protest rally is being arranged for 14 August.

Alienation of the research community could have serious consequences for the Russian government. Although the scientific intelligentsia has hitherto been one of the chief sources of support for democratic reform, there are now ominous signs that some of its members are moving towards what Yeltsin calls the "irreconcilable opposition".

Although the views of the union leaders at the meeting on 30 June do not represent those of the scientific community, the expressions of nationalism heard at the meeting are worrying. One opinion was that Russian science is being deliberately starved in order to crush the Russian nation "by the castration of its brains". Many will interpret these sentiments as a measure of people's desperation, but if they are widely echoed, they could become dangerous.

Vladimir Pokrovsky 